\title{
Pituitary Adenylate Cyclase-Activating Polypeptide (PACAP-38) Protects Cerebellar Granule Neurons from Apoptosis by Activating the Mitogen-Activated Protein Kinase (MAP Kinase) Pathway
}

\author{
Martin Villalba, Joël Bockaert, and Laurent Journot \\ Centre National de la Recherche Scientifique (CNRS), Unité Propre de Recherche 9023, Centre CNRS-Institut National \\ de la Santé et de la Recherche Médicale de Pharmacologie-Endocrinologie, F-34094 Montpellier Cedex 05, France
}

Pituitary adenylate cyclase-activating polypeptides (PACAP-27 and PACAP-38) are neuropeptides of the vasoactive intestinal polypeptide (VIP)/secretin/glucagon family. PACAP receptors are expressed in different brain regions, including cerebellum. We used primary culture of rat cerebellar granule neurons to study the effect of PACAP-38 on apoptosis induced by potassium deprivation. We demonstrated that PACAP-38 increased survival of cerebellar neurons in a dose-dependent manner by decreasing the extent of apoptosis estimated by DNA fragmen- tation. PACAP-38 induced activation of the extracellular signalregulated kinase (ERK)-type of mitogen-activated protein (MAP) kinase through a cAMP-dependent pathway. PD98059, an inhibitor of MEK (MAP kinase kinase), completely abolished the antiapoptotic effect of PACAP-38, suggesting that MAP kinase pathway activation is necessary for PACAP-38 action.

Key words: PACAP; cerebellum; apoptosis; MAP kinase; cAMP; PD 98059
Cerebellar granule cells are among the most abundant neuronal population in the mammalian CNS. During the first few weeks of postnatal life, there is a well documented cell loss in the maturing granule cell layer of the cerebellum (Landis and Sidman, 1978). Cerebellar granule cells undergo apoptosis between postnatal days 5 and 9, whereas cell loss between the third and fifth postnatal weeks is not associated with DNA fragmentation (Wood et al., 1993). In vitro culture of newborn rat cerebellar neurons provided a good model to study neuronal apoptosis because of the high degree of cellular homogeneity (Marini and Paul, 1992). Cerebellar granule cells survive and differentiate in vitro in the presence of depolarizing concentrations of $\mathrm{KCl}(25-30 \mathrm{~mm})$ without additional need for neurotrophic factors (Gallo et al., 1990). The mechanism of action of $\mathrm{KCl}$ remains obscure so far, but, generally, it is believed that an increase in intracellular $\mathrm{Ca}^{2+}$ concentration (D'Mello et al., 1993; Yan et al., 1994; Galli et al., 1995) and mitogen-activated protein (MAP) kinase activation (Rosen et al., 1995) induced by depolarization are involved. In the presence of a normal concentration of $\mathrm{KCl}(5-10 \mathrm{~mm})$, cerebellar granule cells undergo apoptosis, which is inhibited by different categories of molecules: (1) forskolin (D’Mello et al., 1993) and cholera toxin (Yan et al., 1995a), which raise cAMP levels; (2) IGF-1 (D'Mello et al., 1993), which activates a tyrosine kinase receptor; and (3) agonists of muscarinic cholinergic receptors (Yan et al., 1995b) and metabotropic glutamate receptors (Copani et al., 1995), which stimulate phospholipase C. The effect of

Received Aug. 12, 1996; revised Sept. 30, 1996; accepted Oct. 8, 1996.

M.V. was supported by Centre National de la Recherche Scientifique, La Fondation pour la Recherche Médicale (FRM). This work was supported by Grant ACC-SV4/9504087 from the Ministère de l'Education Nationale et de la Recherche, La Ligue pour la Recherche contre le Cancer, and Boehringer-Ingelheim. We gratefully acknowledge the help of Dr. Mireille Lafon for cerebellar granule cell culture and the generous gift of PD98059 by Dr. Alan R. Saltiel (Parke-Davis Pharmaceutical Research).

Correspondence should be addressed to Dr. Laurent Journot, Centre National de la Recherche Scientifique, UPR 9023, CCIPE, 141 Rue de la Cardonille, F-34094 Montpellier Cedex 05, France.

Copyright (C) 1996 Society for Neuroscience $0270-6474 / 96 / 170083-08 \$ 05.00 / 0$
cAMP is of particular interest because it was also demonstrated in other neuronal systems, such as sympathetic and sensory neurons (Rydel and Greene, 1988), dopamine neurons (Mena et al., 1995), and developing septal cholinergic neurons (Kew et al., 1996). The mechanism underlying the cAMP antiapoptotic effect is not well understood; however, it was suggested that the MAP kinase pathway is involved (Kew et al., 1996). Although cAMP inhibits the MAP kinase cascade in some cell lines (Burgering et al., 1993; Cook and McCormick, 1993; Graves et al., 1993; Sevetson et al., 1993; Wu et al., 1993) and has no effect in rat sympathetic neurons (Virdee and Tolkovsky, 1995), it stimulates MAP kinase cascade in other cell lines, including PC12 (Faure et al., 1994; Frödin et al., 1994). MAP kinase activation also has been involved in the protection of PC12 cells from NGF withdrawal-induced apoptosis (Xia et al., 1995).

Modulation of granule cell loss by physiological agents has not been described carefully. Evidence for the presence of pituitary adenylate cyclase-activating polypeptides (PACAP) and PACAP receptor in the cerebellum is compelling and suggests a physiological role for PACAP in cerebellum development (Lam et al., 1990; Cauvin et al., 1991; Basille et al., 1993, 1995; Hashimoto et al., 1993; Spengler et al., 1993; Favit et al., 1995). PACAPs are neuropeptides of the vasoactive intestinal polypeptide (VIP)/secretin/glucagon family, which are named according to their amino acid number: PACAP-27 and PACAP-38. PACAP-27 corresponds to the $27 \mathrm{~N}$-terminal amino acids of PACAP-38 and displays $68 \%$ homology with VIP. Two classes of PACAP receptors have been described with respect to their pharmacological properties: type I PACAP receptors bind PACAP-27 and -38 two orders of magnitude more potently than VIP, whereas type II PACAP receptors do not discriminate between PACAP-27, -38, and VIP. At present three genes encoding PACAP/VIP receptors have been cloned. $\mathrm{PACAP}_{1}-\mathrm{R}$ corresponds to type I binding sites, whereas $\mathrm{PACAP} / \mathrm{VIP}_{1}-\mathrm{R}$ and $\mathrm{PACAP} / \mathrm{VIP}_{2}-\mathrm{R}$ correspond to type II PACAP receptors. No VIP-specific receptor has been cloned yet. PACAP-38 modulates the release of several pituitary hor- 
mones (Miyata et al., 1989) and of catecholamines from the adrenal gland (Watanabe et al., 1992; Isokobe et al., 1993). In addition, PACAP-38 promotes neurite outgrowth in PC12 cells (Deutsch and Sun, 1992; Hernandez et al., 1995) and NB-OK neuroblastoma (Deutsch et al., 1993), stimulates neuritogenesis and survival of cultured rat sympathetic neuroblasts (Pincus et al., 1990; DiCicco-Bloom and Deutsch, 1992), and prevents natural neuronal cell death in chick embryo and HIV gp120-induced cell death in hippocampal cultures (Arimura et al., 1994). Because of the demonstrated presence of PACAP-38 in the cerebellum and the neurotrophic and neuroprotective activity of PACAP-38 in other systems and because PACAP-38 stimulates cAMP production, we tested PACAP-38 as a modulator of apoptosis in primary culture of cerebellar granule cells.

\section{MATERIALS AND METHODS}

Materials. PACAP was obtained from Neosystem (Strasbourg, France), $\left[\gamma^{-32} \mathrm{P}\right]$ ATP and $\left[2-{ }^{3} \mathrm{H}\right]$ adenine from Isotopchim, Biotrak MAP Kinase Enzyme assay kit from Amersham (Arlington Heights, IL), IGF-1 from Bachem AG (Torrence, CA), Rp-cAMP and Sp-cAMP from RBI, antibody against phospho-ERK from New England Biolabs (Beverly, MA), H89 from Calbiochem (Lucerne, Switzerland), BMEM and BMEMGlutamax-I from Life Technologies (Gaithersburg, MD), and Taq DNA polymerase from Eurobio. PD98059 was a generous gift from Dr. Alan R. Saltiel (Parke-Davis Pharmaceutical Research). All other reagents, unless otherwise indicated, were from Sigma (St. Louis, MO).

Culture of cerebellar granule cells. Rat cerebellar granule neurons were prepared from 8-d-old Wistar rat pups, as previously described (Levi et al., 1984). Briefly, freshly dissected cerebella were incubated with 0.25 $\mathrm{mg} / \mathrm{ml}$ trypsin for $10 \mathrm{~min}$ at $37^{\circ} \mathrm{C}$. Trypsin inhibitor $(0.5 \mathrm{mg} / \mathrm{ml})$ and 0.08 $\mathrm{mg} / \mathrm{ml}$ DNase were added to stop the reaction. Digested cerebella were centrifuged and disrupted mechanically with a Pasteur pipette in the presence of DNase and trypsin inhibitor. Cells were seeded at a density of $0.25 \times 10^{6}$ cells $/ \mathrm{cm}^{2}$ in Falcon dishes coated with poly-L-lysine in BMEM supplemented with $10 \%$ fetal calf serum (FCS), $10 \mathrm{U}$ of penicillin, $10 \mu \mathrm{g}$ of streptomycin, $30 \mathrm{~mm} \mathrm{KCl,} 10 \mathrm{~mm}$ HEPES, $\mathrm{pH}$ 7.4, $17 \mathrm{~mm}$ glucose, and $2 \mathrm{~mm}$ glutamine. After $24 \mathrm{hr}, 10 \mu \mathrm{M}$ cytosine arabinoside was added to the culture medium. Cultures were used after $7 \mathrm{~d}$ in vitro (DIV).

Neuronal viability. Viable granule neurons were quantified as previously described (Didier et al., 1990). Briefly, 7 DIV cultures were washed twice with $\mathrm{HK}$ medium (BMEM-glutamax-I supplemented with $30 \mathrm{mM} \mathrm{KCl}, 10$ mM HEPES, $\mathrm{pH} 7.4$, and $17 \mathrm{~mm}$ glucose) and cultivated for $48 \mathrm{hr}$ in $\mathrm{HK}$ or LK medium (BMEM-glutamax-I supplemented with $10 \mathrm{mM} \mathrm{KCl,} 10$ mM HEPES, $\mathrm{pH} 7.4$, and $17 \mathrm{~mm}$ glucose) with or without the different drugs. For control cultures in serum-containing medium, the cells were washed twice with HK medium and refed with culture medium used throughout the culture to avoid the neurotoxic effect of fresh serumcontaining medium (Yan et al., 1994). Cultures were exposed to $15 \mu \mathrm{g} / \mathrm{ml}$ fluorescein diacetate (FDA) for $10 \mathrm{~min}$ at $37^{\circ} \mathrm{C}$. The medium was aspirated, and lysis buffer (15 mM Tris- $\mathrm{HCl}, \mathrm{pH} 7.4$, and $1 \% \mathrm{SDS}$ ) was added. After $15 \mathrm{~min}$, the supernatant was collected, and the amount of fluorescein was determined with a spectrofluorometer.

Quantification of DNA fragmentation. Cultures (7 DIV) were washed twice with HK medium. HK or LK medium with or without the different drugs was added for $24 \mathrm{hr}$. In experiments in which antagonists were tested, neurons were preincubated for $1 \mathrm{hr}$ with the antagonists in serum-containing medium to allow loading of the cells. Neurons $\left(5 \times 10^{6}\right)$ were trypsinized, scraped, and collected by centrifugation. Three hundred microliters of lysis buffer $(0.5 \%$ Triton X-100, $20 \mathrm{~mm}$ EDTA, and $5 \mathrm{~mm}$ Tris- $\mathrm{HCl}, \mathrm{pH}$ 7.4) were added, and incubation was continued for $20 \mathrm{~min}$ at $4^{\circ} \mathrm{C}$. Cells were centrifuged at $27,000 \times g$ for $15 \mathrm{~min}$. Pellets (nuclei plus intact chromatin) were incubated with $300 \mu$ l of lysis buffer plus 100 $\mu \mathrm{g}$ of proteinase $\mathrm{K}$. Proteinase $\mathrm{K}(60 \mu \mathrm{g})$ was added to the supernatant (soluble DNA). Samples were incubated for $2 \mathrm{hr}$ at $60^{\circ} \mathrm{C}$ and then overnight at $37^{\circ} \mathrm{C}$ with gentle shaking. The DNA was extracted with phenol-chloroform. Soluble DNA $(200 \mu \mathrm{l})$ or nonsoluble DNA $(50 \mu \mathrm{l})$ was incubated in TNE buffer (10 mM Tris- $\mathrm{HCl}, \mathrm{pH} 7.4,200 \mathrm{~mm} \mathrm{NaCl}$, and $1 \mathrm{~mm}$ EDTA) with $0.5 \mu \mathrm{g} / \mathrm{ml}$ of Hoechst 33258. Fluorescence was measured with a spectrofluorometer (excitation $356 \mathrm{~nm}$; emission $492 \mathrm{~nm}$ ). Similar results were obtained with the Cell Death Detection ELISA kit from Boehringer Mannheim (Cat. No. 1544 675; Mannheim, Germany).

DNA laddering. DNA extraction was performed as described above.
After phenol-chloroform extraction, the DNA was precipitated with ethanol, resuspended in TE buffer $(10 \mathrm{~mm}$ Tris- $\mathrm{HCl}, \mathrm{pH} 8.0$, and $1 \mathrm{~mm}$ EDTA) supplemented with $2 \mu \mathrm{g} / \mathrm{ml}$ RNase A, and incubated overnight at $37^{\circ} \mathrm{C}$. Samples were electrophoresed through a $1.2 \%$ agarose gel. DNA was visualized by ethidium bromide staining.

Photomicrographs. Cultures (7 DIV) were incubated for $48 \mathrm{hr}$ as indicated above with the different drugs. Cells were incubated with FDA as indicated above and photographed with a phase-contrast microscope or with a fluorescence microscope using the fluorescein filter after three washes with PBS. For propidium iodide staining, 7 DIV cultures were incubated for $48 \mathrm{hr}$ as indicated above with the different drugs. At the end of the incubation period, cells were fixed with $3 \%$ paraformaldehyde in PBS and then permeabilized with $0.2 \%$ Triton X-100 in PBS for 15 min at room temperature. Cells were incubated overnight with $50 \mu \mathrm{g} / \mathrm{ml}$ propidium iodide at $4^{\circ} \mathrm{C}$. After three washes with PBS, coverslips were mounted with Mowiol and examined by fluorescence microscopy using a rhodamine filter.

Extracellular signal-regulated kinase (ERK) activity. ERK activity was determined by the Biotrak p42/p44 MAP kinase enzyme assay kit as recommended by the manufacturer (Amersham). Briefly, 7 DIV cultures were washed twice with HK medium. HK or LK medium with or without the different drugs was added for $10 \mathrm{~min}$ at $37^{\circ} \mathrm{C}$. In experiments in which antagonists were tested, neurons were preincubated for $1 \mathrm{hr}$ with the antagonists in serum-containing medium to allow loading of the cells. The incubations were terminated by aspiration, and the cells were lysed immediately in lysis buffer containing (in mM): Tris- $\mathrm{HCl} 10, \mathrm{pH} \mathrm{7.4,} \mathrm{NaCl}$ 150, EGTA 2, DTT 2, orthovanadate 1, and PMSF 1 with $10 \mu \mathrm{g} / \mathrm{ml}$ leupeptin, $10 \mu \mathrm{g} / \mathrm{ml}$ aprotinin, and $0.2 \%$ Triton X-100. Cell extract $(15 \mu \mathrm{l})$ was mixed with $10 \mu \mathrm{l}$ of substrate buffer containing an ERK-specific peptide substrate, and the reaction was started by adding $5 \mu$ lof $\left[\gamma^{32} \mathrm{P}\right]-$ ATP. After $30 \mathrm{~min}$ at $30^{\circ} \mathrm{C}$, the reaction was terminated by adding $10 \mu \mathrm{l}$ of stop reagent containing orthophosphoric acid. Then $30 \mu \mathrm{l}$ was pipetted onto the center of paper disks, followed by washing twice in $75 \mathrm{~mm}$ orthophosphoric acid for $2 \mathrm{~min}$ and twice in water for $2 \mathrm{~min}$. Disks containing phosphorylated peptide were counted on a scintillation counter.

Detection of phospho-ERKs. After incubation for $10 \mathrm{~min}$ at $37^{\circ} \mathrm{C}$ as described above for determination of ERK activity, 7 DIV cultures were lysed in Laemmli buffer. Samples were electrophoresed through a 10\% acrylamide gel and blotted on a nitrocellulose membrane. Membranes were treated with a phospho-specific MAPK antibody (1:1000; New England Biolabs) and developed with the Phototope-Star Western Blot Detection kit (New England Biolabs). Then membranes were stripped with stripping solution (100 mm Tris- $\mathrm{HCl}, \mathrm{pH} 6.7,2 \%$ SDS, and $100 \mathrm{~mm}$ $\beta$-mercaptoethanol), incubated with anti-ERK1 and anti-ERK2 antibodies (1:400 each; Santa Cruz Biotechnology, Tebu, France), and developed with the Renaissance Western detection kit (Dupont NEN, Boston, MA).

Determination of cAMP levels. Cultures (7 DIV) were washed twice with HK medium and incubated for $2 \mathrm{hr}$ in the presence of $\left[2-{ }^{3} \mathrm{H}\right]$ adenine in HK medium. Cells were incubated in the same medium supplemented with $0.5 \mathrm{~mm} 3$-isobutyl-1-methylxanthine (IBMX) for $15 \mathrm{~min}$ at $37^{\circ} \mathrm{C}$. Various concentrations of PACAP or VIP were added for $15 \mathrm{~min}$. The medium was aspirated, and the reaction was stopped by the addition of 1 $\mathrm{ml}$ of $5 \%$ trichloroacetic acid (TCA) at $4^{\circ} \mathrm{C}$. Cells then were scraped and centrifuged. cAMP levels in the supernatant were measured as previously described (Salomon et al., 1974).

RT-PCR experiments. Total RNA was prepared from 7 DIV cultures using standard techniques (Chomczynski and Sacchi, 1987). RT-PCR reaction was performed as described (Rawlings et al., 1995). Single-stranded cDNA was synthesized from total RNA with the following protocol. One microliter of total RNA $(3 \mu \mathrm{g} / \mu \mathrm{l})$ was preincubated with $3 \mu \mathrm{l}$ of a hexamer random primer mixture $(100 \mu \mathrm{M})$ and $22.5 \mu \mathrm{l}$ of $\mathrm{H}_{2} \mathrm{O}$ at $70^{\circ} \mathrm{C}$ for $10 \mathrm{~min}$ and then rapidly chilled on ice. To this reaction were added $1 \mu \mathrm{l}$ of RNasin ( $40 \mathrm{U} / \mu \mathrm{l}), 10 \mu \mathrm{l}$ of $5 \times$ RT buffer, $5 \mu \mathrm{l}$ of dithiothreitol $(100 \mathrm{~mm})$, and $2.5 \mu \mathrm{l}$ of deoxyribonucleotides (dNTP; $10 \mathrm{~mm}$ of each), and the mixture was incubated at $45^{\circ} \mathrm{C}$ for $2 \mathrm{~min}$. Finally, $5 \mu \mathrm{l}$ of Moloney murine leukemia virus reverse transcriptase (MoMuLVRT; $200 \mathrm{U} / \mu \mathrm{l}$ ) was added to give a final volume of $50 \mu \mathrm{l}$; the reaction was incubated at $45^{\circ} \mathrm{C}$ for $60 \mathrm{~min}$ and then terminated by placing it on ice. The template produced from the RT reaction was amplified using one of three sets of primers, dependent on the PACAP/VIP receptor we wished to identify. For all three receptors we used primers that flank the putative third intracellular loop of the receptor. For PACAP ${ }_{1}-\mathrm{R}$, the two primers used were PAC1-FL (5'-TTTCATCGGCATCATCATCATCATCCTT-3') and PAC1-VK (5'-CCTTCCAGCTCCTC-CATTTCCTCTT-3'), which would be expected to produce PCR product sizes of 280 base pairs (bp) for 
B

\section{A}

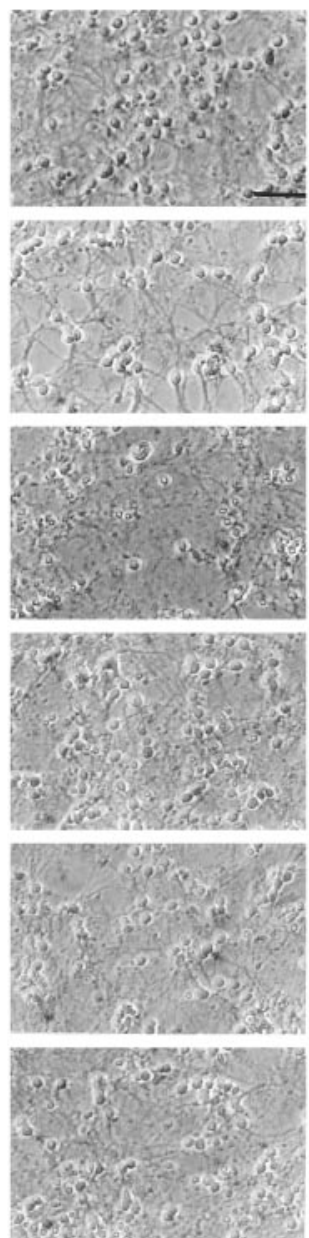

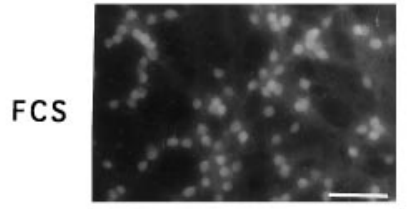

HK

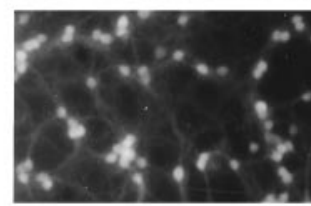

LK

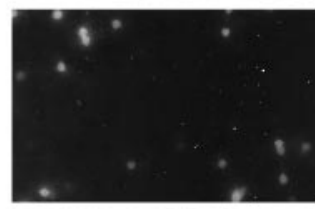

IGF

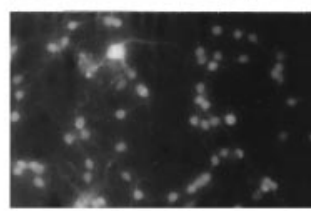

P3 8

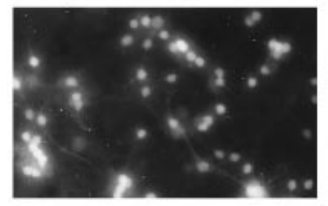

FK

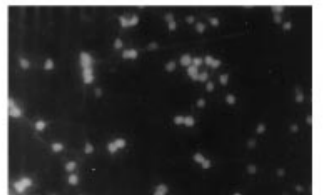

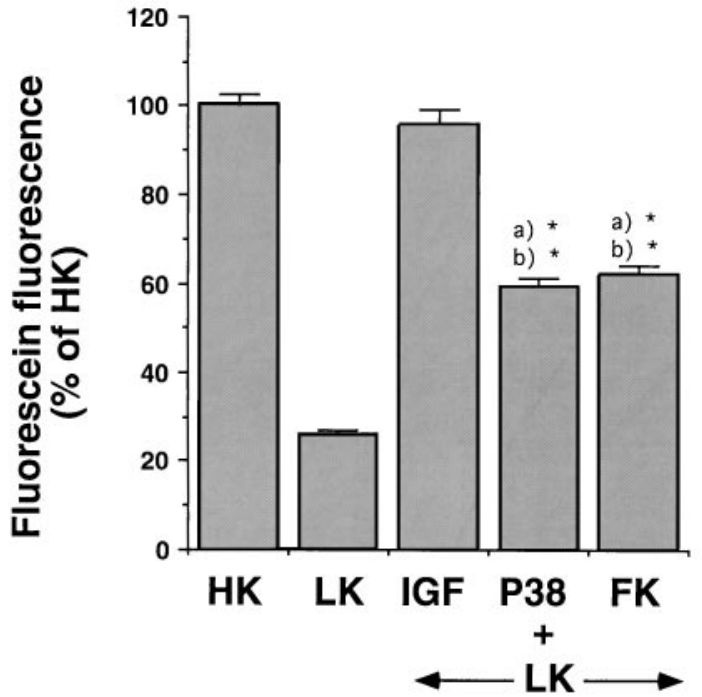

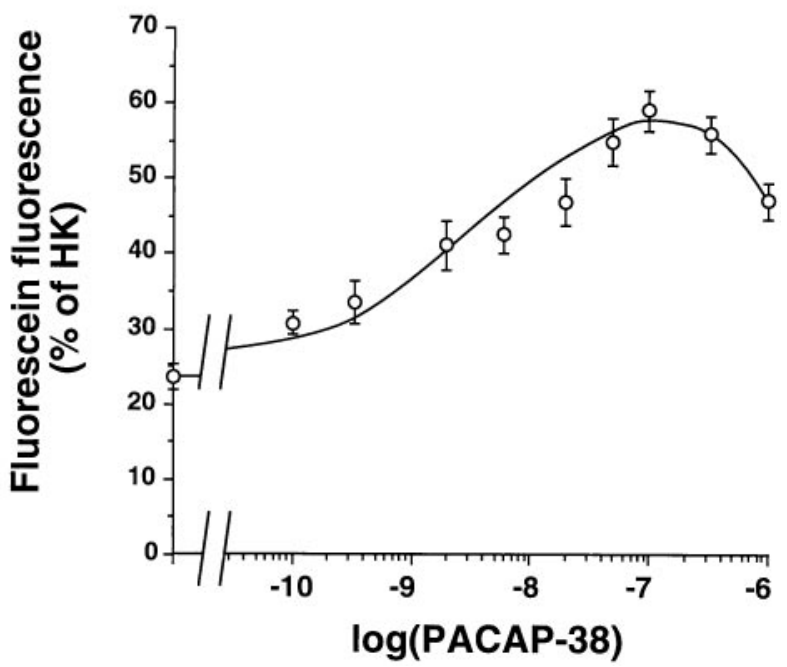

Figure 1. PACAP-38 increases survival of cerebellar granule neurons. $A$, Seven-day-old neurons were deprived of serum and maintained for 48 hr in serum-containing medium $(F C S)$, HK medium $(H K)$, LK medium $(L K)$, or LK medium supplemented with $25 \mathrm{ng} / \mathrm{ml} \mathrm{IGF-1} \mathrm{(IGF),} 100 \mathrm{nM}$ PACAP38 $(P 38)$, or $10 \mu \mathrm{M}$ forskolin $(F K)$. Then cultures were incubated with FDA and photographed by phase-contrast and fluorescence microscopy. Magnification bar, $50 \mu \mathrm{m}$. $B$, Survival was determined by the FDA method (see Materials and Methods). Results were expressed as the percentage of total fluorescein production in sister cultures treated with HK medium. Data are the mean \pm SEM of three independent experiments performed in triplicate. ${ }^{*} p<0.0005$ with Student's $t$ test, as compared with $(a) H K$ and $(b) L K$. $C$, Dose-response curve of PACAP-38-induced increase in FDA conversion. Data are the mean \pm SEM of three independent experiments performed in triplicate.

the "short" variant, 361 bp for the "hop2" variant, 364 bp for the "hip" or "hop1" variants, 445 for the "hip-hop2" variant and 448 bp for the "hiphop1" variant (Spengler et al., 1993). For PACAP/VIP - R, the primers used were VIP1-AI (5'-GCCCCCATCCTCCTCTCCATC-3') and VIP1-EL (5'TCCGCCTGCACCTCACCATTG- $3^{\prime}$ ), which should give a PCR product of 299 bp (Ishihara et al., 1992). The PACAP/VIP $2-\mathrm{R}$ primers used were VIP2-AE (5'-ATGGATAGCAACTCGCCTTTCTTTAG-3') and VIP2-QL (5'-GGAAGGAACCAACACATAACTCAAACAG-3'), yielding a predicted PCR product 325 bp in length (Lutz et al., 1993). For the PCR reaction, $29 \mu \mathrm{l}$ of $\mathrm{H}_{2} \mathrm{O}, 5 \mu \mathrm{l}$ of $10 \times$ PCR buffer, $4 \mu \mathrm{l}$ of $\mathrm{MgCl}_{2}(25 \mathrm{mM}), 1$ $\mu \mathrm{l}$ of dNTP (10 mM of each), $0.5 \mu \mathrm{l}$ of Taq DNA polymerase $(5 \mathrm{U} / \mu \mathrm{l}), 0.25$ $\mu \mathrm{l}$ of both the relevant oligonucleotide primers $(50 \mu \mathrm{M})$, and $5 \mu \mathrm{l}$ of the relevant RT products (or, for the controls, $5 \mu \mathrm{l}$ of the RT reaction in which reverse transcriptase had been omitted) were added to each tube to give a final volume of $50 \mu \mathrm{l}$. The PCR reaction was run on a GeneAmp PCR system 9600 (Perkin-Elmer/Cetus, Norwalk, CT) at $94^{\circ} \mathrm{C}$ for $1 \mathrm{~min}$, followed by $35 \mathrm{cycles}$ of $94^{\circ} \mathrm{C}$ for $30 \mathrm{sec}, 58^{\circ} \mathrm{C}$ for $30 \mathrm{sec}, 72^{\circ} \mathrm{C}$ for $45 \mathrm{sec}$, and then a final cycle of $72^{\circ} \mathrm{C}$ for $420 \mathrm{sec}$. Because the same primer pair is used to amplify all variants of the PACAP $-\mathrm{R}$, the relative abundance of the PCR products is a qualitative index of the abundance of the corresponding transcripts. This point was verified by mixing various proportions of different plasmids containing, each, a different insert encoding a different variant (data not shown).

\section{RESULTS}

Cultures (7 DIV) were washed and incubated with HK medium or LK medium with or without the different drugs, as indicated in Materials and Methods. Viable cells were visualized by staining with FDA (Fig. 1A). As previously reported (D'Mello et al., 1993), decreasing potassium concentration induced a large decrease in the number of cells stained by FDA, and this effect was abrogated by IGF-1 and partially abolished by compounds raising cAMP levels, such as forskolin (Fig. 1A). Interestingly, the effect of forskolin was reproduced fully by PACAP-38 (Fig. 1A). For more quantitative results, we measured cell survival via the FDA conversion technique (Fig. $1 B$ ). The decrease in potassium concentration induced a large decrease in FDA conversion, which 


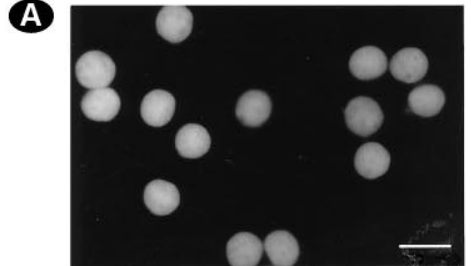

FCS

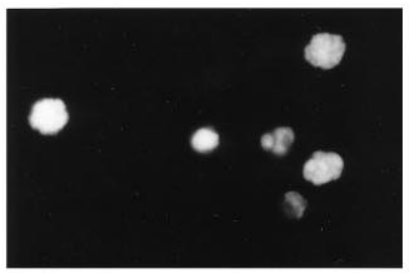

LK

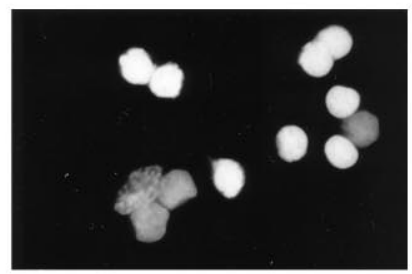

FK

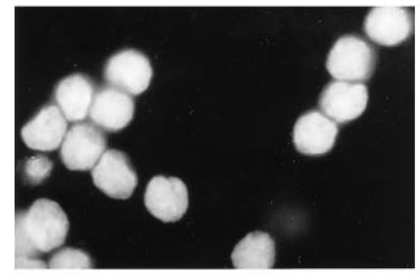

HK

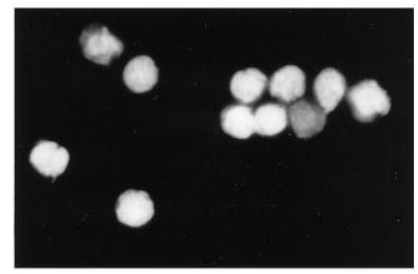

P3 8
B

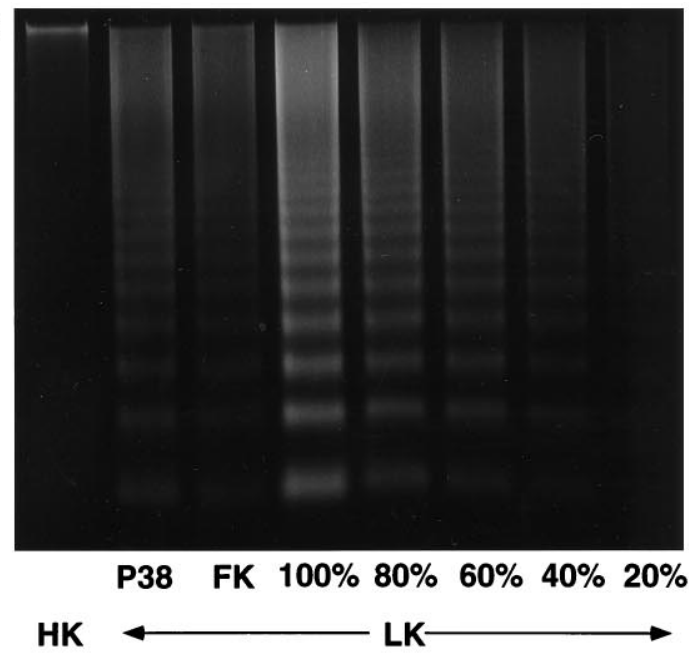

C

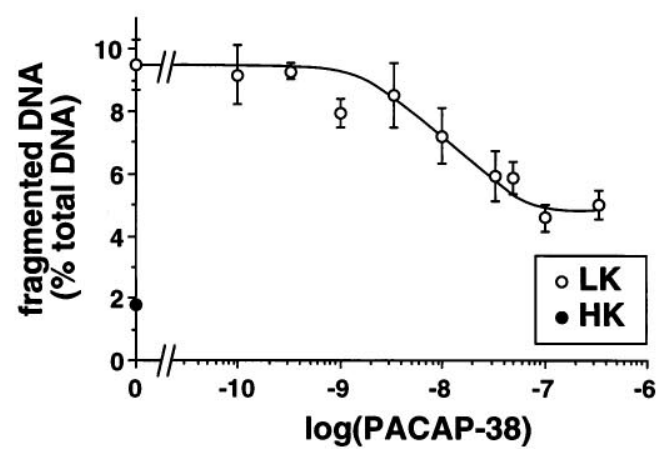

Figure 2. PACAP-38 protects cerebellar granule neurons from apoptosis. $A$, Changes in nuclear morphology. Seven-day-old neurons were deprived of serum and maintained for $24 \mathrm{hr}$ in HK medium $(H K)$, LK medium $(L K)$, or LK medium supplemented with either $100 \mathrm{~nm}$ PACAP-38 (P38) or $10 \mu \mathrm{M}$ forskolin $(F K)$. Control cultures were kept in serum-containing medium $(F C S)$. Magnification bar, $10 \mu \mathrm{m}$. B, PACAP decreased fragmentation of DNA from cerebellar granule cells induced by LK medium. Cultures were incubated as in $A$. Soluble DNA was extracted, electrophoresed, and visualized with ethidium bromide staining. To illustrate quantitatively the extent of protection from DNA laddering by PACAP or forskolin, we loaded a different amount of soluble DNA obtained from one plate incubated in LK medium alone (100-20\%). Data are representative of three independent experiments. $C$, Dose-response curve of PACAP-38-induced decrease in DNA fragmentation. Seven-day-old neurons were deprived of serum and maintained for 24 hr in LK medium supplemented with different PACAP-38 concentrations. Soluble and nonsoluble DNA was isolated and quantified as described in Materials and Methods. Data are the mean \pm SEM of three independent experiments.

was protected partially by forskolin or PACAP-38. Interestingly, protection by PACAP-38 was dose-dependent with a maximal effect at $100 \mathrm{~nm}$ and an $\mathrm{EC}_{50}$ of $5 \mathrm{~nm}$ (Fig. 1C).

A decrease in potassium concentration was reported previously to induce apoptosis in cerebellar granule cells (D'Mello et al., 1993; Yan et al., 1994). Therefore, staining with propidium iodide was performed after permeabilization of the cells. Changing from serum-containing medium to $\mathrm{HK}$ medium did not induce apoptosis (Fig. $2 A$ ). In contrast, the presence of numerous nuclei displaying fragmented or condensed chromatin, a characteristic feature of apoptotic nuclei (Earnshaw, 1995), revealed apoptosis in LK medium (Fig. 2A). Interestingly, PACAP-38 (100 nM) and forskolin $(10 \mu \mathrm{M})$ efficiently protected neurons from apoptosis, because the number of apoptotic nuclei was reduced (Fig. 2A). The biochemical hallmark of apoptosis is nuclear DNA fragmentation into oligonucleosomal fragments, which can be visualized as a DNA ladder by agarose gel electrophoresis of soluble DNA (Wyllie, 1980; Hockenberry et al., 1990). Using this method, we confirmed that potassium deprivation induced apoptosis in cerebellar granule cell cultures and showed that PACAP-38 (100 nM) or forskolin $(10 \mu \mathrm{M})$ decreased the intensity of DNA laddering. High $\mathrm{KCl}$ concentration completely blocked laddering (Fig. 2B).
By comparing the amount of fragmented DNA in the presence of PACAP-38 with different amounts of fragmented DNA from LK condition, we estimated the protective effect of PACAP-38 to $60 \%$ (Fig. $2 B$ ). To have a more quantitative assessment of DNA laddering, we developed a protocol to quantify the proportion of fragmented DNA, as described in Materials and Methods. PACAP-38 protected cerebellar granule neurons from apoptosis in a dose-dependent manner, with a maximal effect $\sim 100 \mathrm{nM}$ (Fig. 2C).

It is noteworthy that the switch from serum-containing medium used throughout the culture to HK medium also induced some cell death (data not shown). However, this death was essentially necrotic, because no DNA laddering and no chromatin condensation were shown in HK medium (Fig. 2B). Furthermore, neither forskolin nor PACAP-38 had any protective effect in HK medium, as compared with HK medium alone, when FDA conversion was measured (data not shown). This indicates that the cells protected by forskolin or PACAP-38 were those dying by apoptosis because of potassium deprivation and not those dying by necrosis because of serum withdrawal.

To identify the PACAP receptor(s) involved, we performed RT-PCR with primers specific for the different PACAP/VIP re- 
A

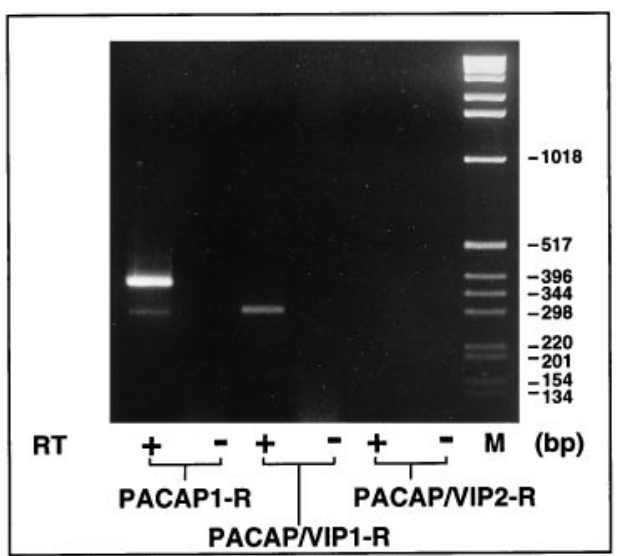

B

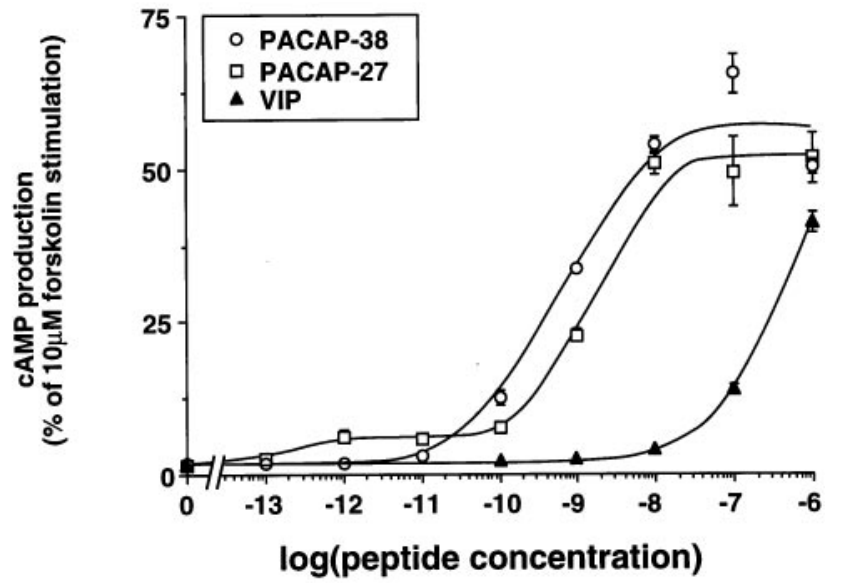

Figure 3. A, Cerebellar granule neurons express predominantly $\mathrm{PACAP}_{1}$-R with one cassette. Seven-day-old neurons were washed twice with HK medium, and total RNA was isolated. After reverse transcription $(\mathrm{RT}+)$ and PCR amplification, DNA was electrophoresed and visualized with ethidium bromide. Reverse transcriptase was omitted in control experiments $(\mathrm{RT}-)$. The predicted fragment size was 280 bp for PACAP $_{1}$-R s (short variant), 361 bp (hop2) or 364 bp (hip or hop1) for a single cassette insert, and 445 bp (hip-hop2) or 448 bp (hip-hop1) for double insert, $299 \mathrm{bp}$ for PACAP/VIP 1 -R, and $325 \mathrm{bp}$ for PACAP/VIP 2 -R. Data are representative of two independent experiments. $B$, PACAP- or VIP-stimulated cAMP production in cerebellar granule cells. Neurons were incubated for $15 \mathrm{~min}$ at $37^{\circ} \mathrm{C}$ in $\mathrm{LK}$ medium containing the indicated concentrations of PACAP-38 (open circles), PACAP-27 (open squares), or VIP (filled triangles). Data are expressed as the percentage of cAMP production induced by $20 \mu \mathrm{M}$ forskolin. Data are the mean \pm SEM of three independent experiments performed in triplicate.

ceptor subtypes and splice variants. We demonstrated the expression of PACAP 1 - R and PACAP/VIP $-\mathrm{R}$ (Fig. $3 A$ ). The products obtained with primers specific for the $\mathrm{PACAP}_{1}-\mathrm{R}$ indicated that variants with one cassette (hip or hop) were expressed preferentially and that the short variant was expressed at much lower levels. Using restriction enzymes that are specific for the hip (AvaII) or hop (Bpu1102 I) variants (Rawlings et al., 1995), we identified the one cassette band as PACAP $_{1}-\mathrm{R}$ hop (data not shown). Conclusively, cerebellar granule cells mainly express PACAP $_{1}$-R hop mRNA. In addition, we performed pharmacological characterization of the expressed PACAP/VIP receptor(s) (Fig. $3 B$ ). Stimulation of cAMP production by PACAP and VIP indicated the presence of type I PACAP receptor, which is compatible with RT-PCR experiments. On the other hand, the potency of VIP to stimulate cAMP production was low, indicating that no type II PACAP receptor (PACAP/VIP 1 - R or PACAP/
$\left.\mathrm{VIP}_{2}-\mathrm{R}\right)$ was expressed significantly in contrast to what was anticipated from RT-PCR experiments.

Because activation of the MAP kinase pathway has been involved in protection from apoptosis and because cAMP has been shown to stimulate MAP kinase activity in some experimental systems, we measured PACAP-stimulated ERK activity. PACAP-38 stimulated ERK activity in a dose-dependent manner with a maximal effect at $100 \mathrm{~nm}$ (Fig. $4 A$ ). We demonstrated that tetrodotoxin (TTX) did not block PACAP-induced stimulation of MAP kinase activity (Fig. $4 B$ ), suggesting that the effect of PACAP was not mediated by the release of neurotransmitters or neurotrophic factors. Rp-cAMP and H89, two inhibitors of PKA, and PD98059, an inhibitor of MEK, blocked stimulation of ERK activity by PACAP-38 and forskolin (Fig. 4C). We extended our analysis by performing Western blots with anti-phospho-ERK antibodies. We demonstrated that ERK2 was more abundant than ERK1 and that PACAP-38 induced phosphorylation of both kinases (Fig. 4D). Modulation of the phosphorylation state of ERK1 and ERK2 by the different treatments was in agreement with results obtained by the measurement of ERK activity.

To test whether PACAP-induced ERK activation was involved in the anti-apoptotic effect of PACAP-38, we measured DNA fragmentation in the presence of PD98059 and Rp-cAMP. Both compounds did not affect the protection induced by high $\mathrm{KCl}$ concentrations, excluding toxic or nonspecific effect (Fig. 5). Interestingly, both PD98059 and Rp-cAMP blocked the effect of PACAP-38 on DNA fragmentation (Fig. 5).

\section{DISCUSSION}

It was reported recently that forskolin, a direct activator of adenylyl cyclase, and cholera toxin (CTX), an activator of $\mathrm{G}_{\mathrm{s}}$, protected cerebellar granule cells from cell death (D'Mello et al., 1993; Galli et al., 1995; Yan et al., 1995a). However, no physiological activator of the cAMP pathway displaying the same protective effect was characterized. In the present work, we demonstrated that PACAP-38 was as efficient as forskolin in protecting cerebellar granule cells from $\mathrm{KCl}$ deprivation-induced apoptosis. Arimura and coworkers reported a neurotrophic biphasic effect of low PACAP-38 concentrations on gp120-induced apoptosis in hippocampal cultures (Arimura et al., 1994). At concentrations above 1 nM, PACAP-38 was not effective in that system. In contrast, the effect of PACAP-38 on cerebellar granule neurons was monophasic, with a maximum at $100 \mathrm{~nm}$. The effect of PACAP-38 on cerebellar granule neurons is, therefore, likely to involve mechanisms different from those recruited in hippocampal cultures.

Using RT-PCR, we demonstrated the presence of PACAP $_{1}-\mathrm{R}$ and PACAP/VIP $-\mathrm{R}$ mRNAs. In addition, the PACAP $\mathrm{P}_{1}-\mathrm{R}$ gene is spliced alternatively and generates different variants with possible insertion of two cassettes named "hip" and "hop" in the third intracellular loop of the receptor (Spengler et al., 1993). RT-PCR experiments revealed the presence of two variants: (1) PACAP $1-R$ $\mathrm{s}$ (short), which does not contain any insert, and (2) $\mathrm{PACAP}_{1}-\mathrm{R}$ hop, a variant with one insertion. These results are in agreement with recently published experiments by D'Agata and coworkers (1996), who showed a major PCR product corresponding to the hop variant at postnatal day $4(\mathrm{P} 4)$ and P8. Interestingly, at P25 the major PCR product corresponded to the short variant, suggesting a possible role for alternative splicing of the $\mathrm{PACAP}_{1}-\mathrm{R}$ during postnatal development of the cerebellum. We confirmed expression of the $\mathrm{PACAP}_{1}-\mathrm{R}$ protein by measuring PACAP- and VIP-stimulated cAMP production. Although expression of 
A

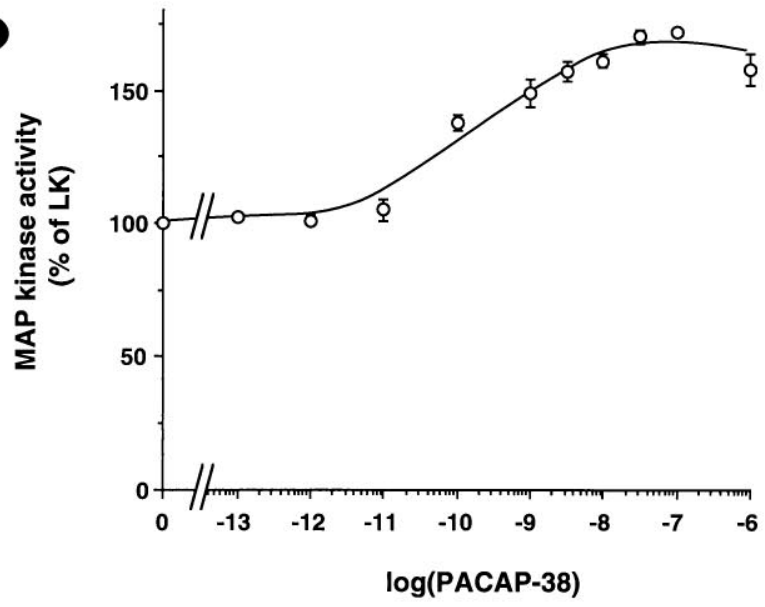

C

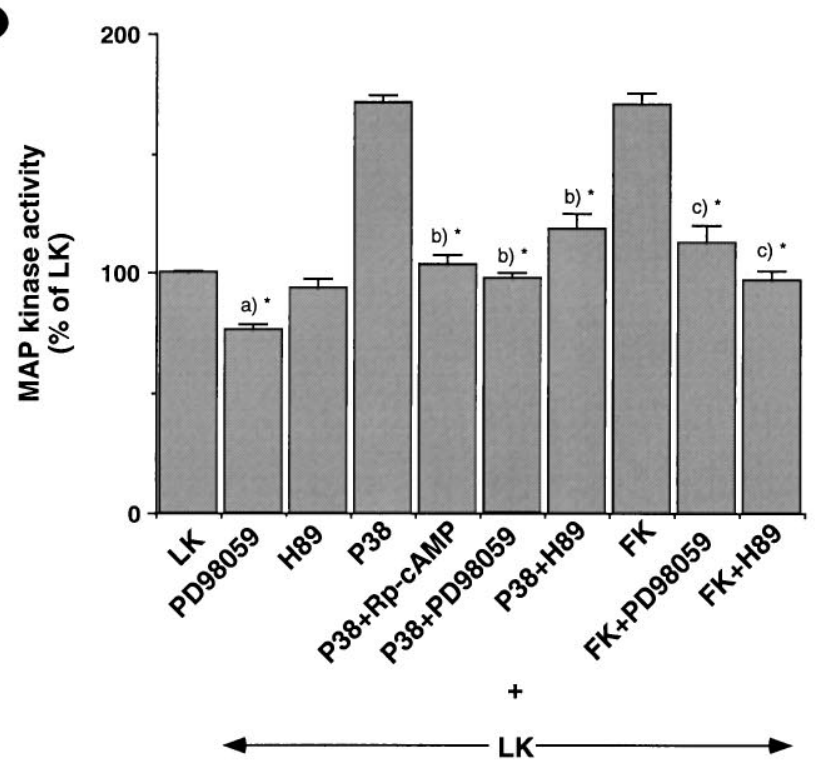

B

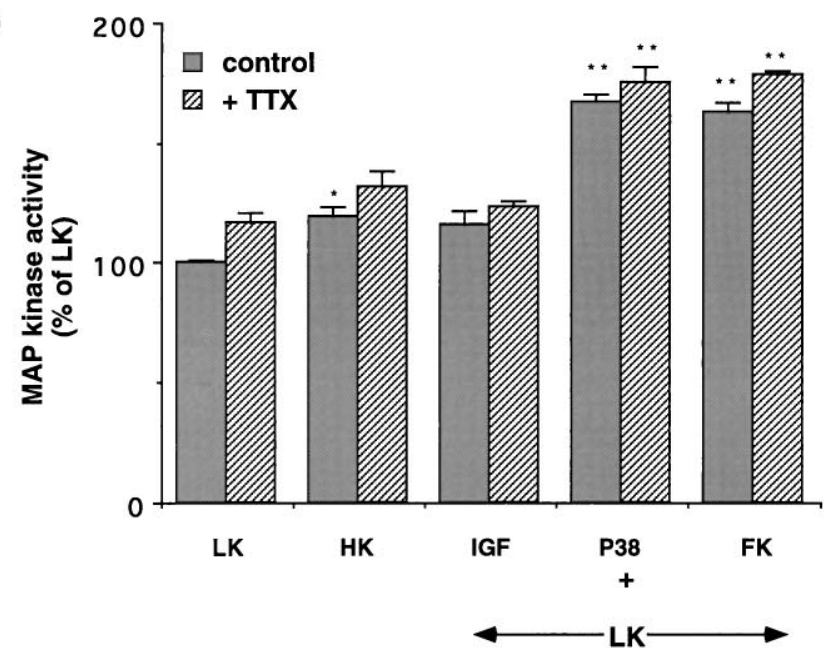

(D)

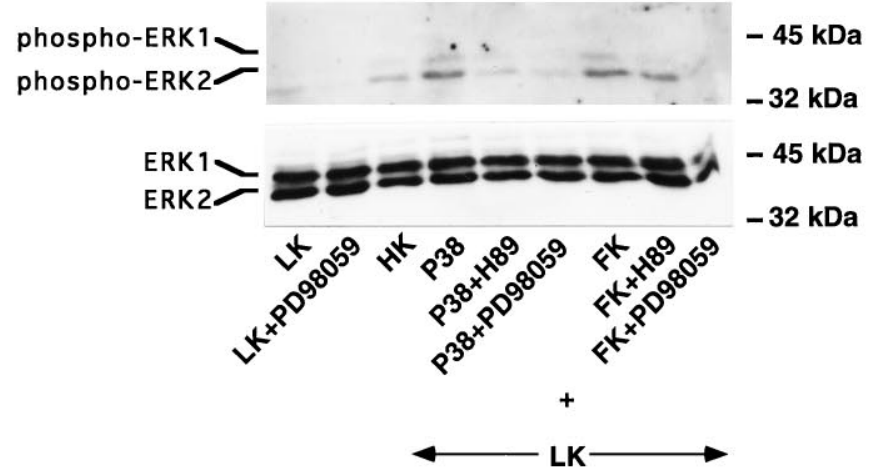

Figure 4. A, PACAP-38 stimulated MAP kinase activity. Neurons were incubated with the indicated concentrations of PACAP-38 for 10 min at $37^{\circ} \mathrm{C}$. MAPK activity was determined as described in Materials and Methods. Data are expressed as the percentage of MAP kinase activity in LK medium alone. Data are the mean \pm SEM of three independent experiments performed in triplicate. $B$, PACAP-38 and forskolin induced MAPK activation independently of neuronal activity. Neurons were incubated for $1 \mathrm{hr}$ in the presence of $1 \mu \mathrm{M}$ tetrodotoxin $(T T X)$ and then stimulated with HK medium, $100 \mathrm{~nm}$ PACAP-38, or $10 \mu \mathrm{M}$ forskolin for $10 \mathrm{~min}$. Data are the mean \pm SEM of three independent experiments performed in triplicate. * $p<0.005 ;{ }^{* *} p<$ 0.0005 with Student's $t$ test. Values were compared with the corresponding control (LK alone or LK + TTX). C, PACAP stimulates MAP kinase activity via a PKA- and MEK-dependent mechanism. Neurons were incubated for $1 \mathrm{hr}$ in the presence or absence of different inhibitors $(25 \mu \mathrm{M}$ PD98059; $20 \mu \mathrm{M}$ $\mathrm{H} 89 ; 200 \mu \mathrm{M} \mathrm{Rp}$-cAMP), washed twice, and incubated at $37^{\circ} \mathrm{C}$ for $10 \mathrm{~min}$ with $100 \mathrm{nM}$ PACAP-38 and $10 \mu \mathrm{m}$ forskolin in the presence or absence of the inhibitors. Data are the mean \pm SEM of three independent experiments performed in triplicate. ${ }^{*} p<0.0005$ with Student's $t$ test, as compared with $(a)$ $L K,(b)$ PACAP-38 (P38), and (c) forskolin $(F K)$. D, PACAP-38 and forskolin-induced phosphorylation of ERK1 and ERK2. Western blotting with an antibody specific for phosphorylated ERKs was performed as described in Materials and Methods. Western blotting with an antibody against total ERKs is shown to document equal loading.

PACAP/VIP ${ }_{1}$-R mRNA was demonstrated with RT-PCR, pharmacological characterization indicated that $\mathrm{PACAP} / \mathrm{VIP}_{1}-\mathrm{R}$ protein was expressed at very low level, because VIP did not stimulate cAMP formation potently. The effect of PACAP-38 on cerebellar granule cells was, therefore, mediated mainly by $\mathrm{PACAP}_{1}-\mathrm{R}$ activation. Basille and coworkers documented the presence of PACAP receptors on cells of the proliferating external granule cell layer (EGL) at P8 (Basille et al., 1993). At that time, granule cells undergo both maximal proliferation and massive DNA fragmentation, indicating that apoptosis occurs in the EGL very soon after neurogenesis, before maximal migration to the internal granule cell layer (IGL), and synaptogenesis with Purkinje cells occurs $\sim \mathrm{P} 10$. This indicates that factors other than synaptogenesis must regulate the number of granule cells that survive (Wood et al., 1993). The present work suggests that PACAP-38 might be one of these factors.

Most neurotrophic factors concurrently participate in neuronal differentiation and protection from apoptosis. It is, therefore, not surprising that these two processes involve common mechanisms, and studies on neuronal differentiation help to elucidate mechanisms underlying protection from apoptosis. PACAP-38 was shown to display neurotrophic properties in several systems, namely PC12 (Deutsch and Sun, 1992), sympathetic neurons (Pincus et al., 1990; DiCicco-Bloom and Deutsch, 1992), and 


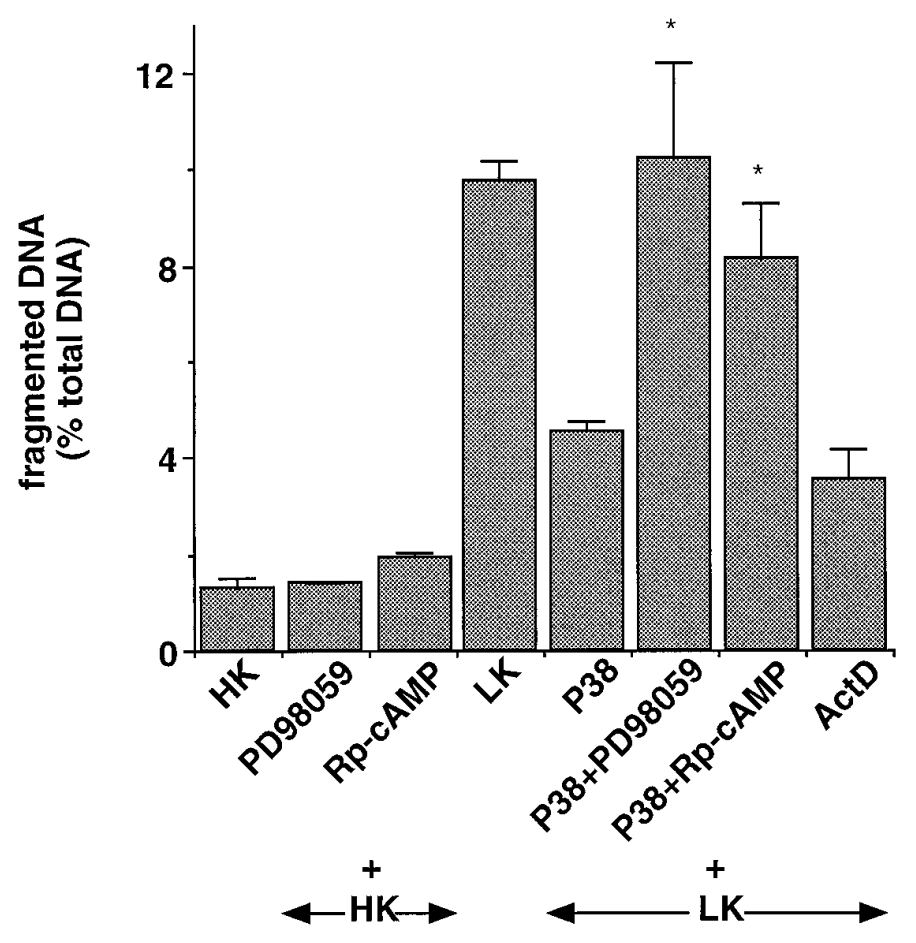

Figure 5. PACAP-38 decreased DNA fragmentation via a PKA- and MEK-dependent mechanism. Neurons were incubated with $25 \mu \mathrm{M}$ PD98059 or $200 \mu \mathrm{M} \mathrm{Rp}$-cAMP for $1 \mathrm{hr}$ before the addition of $100 \mathrm{nM}$ PACAP-38 or $2 \mu \mathrm{g} / \mathrm{ml}$ actinomycin D. Cells were washed twice with HK medium and incubated with different drugs and inhibitors for $24 \mathrm{hr}$. Soluble and nonsoluble DNA were isolated and quantified, as indicated in Materials and Methods. Data are the mean \pm SEM of at least three independent experiments. ${ }^{*} p<0.005$ with Student's $t$ test, as compared with PACAP-38 alone.

chick embryo and hippocampal cultures (Arimura et al., 1994). In PC12 cells, it was demonstrated that MAP kinase activation is necessary and sufficient for differentiation (Cowley et al., 1994) and that blockade of the MAP kinase pathway by PD98059, a specific MEK inhibitor (Alessi et al., 1995; Dudley et al., 1995), prevented differentiation of PC12 cells by NGF (Pang et al., 1995). Interestingly, it also was shown that cAMP-induced differentiation was accompanied by activation of the MAP kinase pathway (Frödin et al., 1994; Young et al., 1994) and that PACAP-38 stimulates ERK1 activity (Frödin et al., 1994). These results suggested a possible mechanism for PACAP-38 action on cerebellar granule cells. Conversely, Edwards et al. (1991) demonstrated that cAMP protected sympathetic neurons from NGF withdrawal-induced apoptosis without activating ERK (Virdee and Tolkovsky, 1995). In cerebellar granule cells we demonstrated that PACAP-38 stimulated ERK1 and ERK2 activity and phosphorylation. Interestingly, Rp-cAMP and H89, two inhibitors of PKA, totally blocked ERK stimulation by PACAP-38, indicating that activation of PKA is necessary for PACAP-induced ERK activation (Fig. $4 C$ ). In addition, we showed that blockade of the cAMP pathway with Rp-cAMP or of the MAP kinase pathway with PD98059 abrogated the antiapoptotic effect of PACAP-38. Conclusively, protection of cerebellar granule cells by PACAP-38 likely involves the same mechanism as the one suggested in PC12 cells for cAMP-induced differentiation, namely activation of PKA, which stimulates MEK activity, resulting in activation of ERK. The precise pathway linking PKA activation to stimulation of MEK activity remains elusive at present (Frödin et al., 1994; Young et al., 1994).
Interestingly, we also demonstrated that activation of the MAP kinase pathway is not the exclusive way to protect cerebellar granule neurons from $\mathrm{KCl}$ deprivation-induced cell death. For instance IGF-1 or high $\mathrm{KCl}$ concentration protected neurons (Fig. 1) but weakly stimulated ERK activity (Fig. 4B) (data not shown). Furthermore, the protective effect of $\mathrm{KCl}$ was not affected by PD98059 (Fig. 5). This suggests that other pathways, which work independently of ERK activation, possibly are involved in protection from apoptosis. Xia and coworkers (1995) recently proposed that NGF withdrawal-induced apoptosis of PC12 cells requires concurrent activation of the stress kinases [C-Jun N-terminal protein kinase (JNK) and p38] and inhibition of ERK kinases. Hence, either stimulation of ERK activity or inhibition of the $\mathrm{JNK} / \mathrm{p} 38$ pathway could result in the same protection from apoptosis.

In the present work, we investigated the effect of activation of adenylyl cyclase and ERKs by PACAP-38 during cerebellar granule cells apoptosis and demonstrated that it is necessary to the antiapoptotic effect of PACAP-38. PACAP 1 - R also stimulates phospholipase $\mathrm{C}$ at high PACAP-38 concentrations. Further work will be necessary to evaluate the relevance of possible crosstalk between AC and PLC pathways. Finally, generation of a mouse strain deficient for $\mathrm{PACAP}_{1}-\mathrm{R}$ gene will be a helpful tool to assess the effect of PACAP-38 on cerebellum development in vivo.

\section{REFERENCES}

Alessi DR, Cuenda A, Cohen P, Dudley DT, Saltiel AR (1995) PD 098059 is a specific inhibitor of the activation of mitogen-activated protein kinase kinase in vitro and in vivo. J Biol Chem 270:27489-27494. Arimura A, Somogyvari-Vigh A, Weill C, Fiore RC, Tatsuno I, Bay V, Brenneman DE (1994) PACAP functions as a neurotrophic factor. Ann NY Acad Sci 739:228-243.

Basille M, Gonzalez BJ, Leroux P, Jeandel L, Fournier A, Vaudry H (1993) Localization and characterization of PACAP receptors in the rat cerebellum during development: evidence for a stimulatory effect of PACAP on immature cerebellar granule cells. Neuroscience 57:329-338.

Basille M, Gonzalez BJ, Desrues L, Demas M, Fournier A, Vaudry H (1995) Pituitary adenylate cyclase-activating polypeptide (PACAP) stimulates adenylyl cyclase and phospholipase $\mathrm{C}$ activity in rat cerebellar neuroblasts. J Neurochem 65:1318-1324.

Burgering BM, Pronk GJ, van Weeren PC, Chardin P, Bos LJ (1993) cAMP antagonizes p21ras-directed activation of extracellular signalregulated kinase 2 and phosphorylation of mSos nucleotide exchange factor. EMBO J 12:4211-4220.

Cauvin A, Robberecht P, De Neef P, Gourlet P, Vandermeers A, Vandermeers-Piret M-C, Christophe J (1991) Properties and distribution of receptors for pituitary adenylate cyclase activating peptide (PACAP) in rat brain and spinal cord. Regul Pept 35:161-173.

Chomczynski P, Sacchi N (1987) Single-step method of RNA isolation by acid guanidinium thiocyanate-phenol-chloroform extraction. Anal Biochem 162:156-159.

Cook S, McCormick F (1993) Inhibition by cAMP of Ras-dependent activation of Raf. Science 262:1069-1072.

Copani A, Bruno VMG, Barresi V, Battaglia G, Condorelli DF, Nicoletti F (1995) Activation of metabotropic glutamate receptors prevents neuronal apoptosis in culture. J Neurochem 64:101-108.

Cowley S, Paterson H, Kemp P, Marshall CJ (1994) Activation of MAP kinase kinase is necessary and sufficient for PC12 differentiation and for transformation of NIH 3T3 cells. Cell 77:841-852.

D'Agata V, Cavallaro S, Stivala F, Travali S, Canonico PL (1996) Tissuespecific and developmental expression of pituitary adenylate cyclaseactivating polypeptide (PACAP) receptors in rat brain. Eur $\mathbf{J}$ Neurosci 8:310-318.

Deutsch PJ, Sun Y (1992) The 38-amino acid form of pituitary adenylate cyclase-activating polypeptide stimulates dual signaling cascades in PC12 cells and promotes neurite outgrowth. J Biol Chem 267:5108-5113. 
Deutsch PJ, Schadlow VC, Barzilai N (1993) 38-Amino acid form of pituitary adenylate cyclase activating peptide induces process outgrowth in human neuroblastoma cells. J Neurosci Res 35:312-320.

DiCicco-Bloom E, Deutsch PJ (1992) Pituitary adenylate cyclase activating polypeptide (PACAP) potently stimulates mitosis, neuritogenesis, and survival in cultured rat sympathetic neuroblasts. Regul Pept 37:319-325.

Didier M, Heaulne M, Soubrié P, Bockaert J, Pin J-P (1990) Rapid, sensitive, and simple method for quantification of both neurotoxic and neurotrophic effects of NMDA on cultured cerebellar granule cells. J Neurosci Res 27:25-35.

D'Mello SR, Galli C, Ciotti T, Calissano P (1993) Induction of apoptosis in cerebellar granule neurons by low potassium: inhibition of death by insulin-like growth factor I and cAMP. Proc Natl Acad Sci USA 90:10989-10993.

Dudley DT, Pang L, Decker SJ, Bridges AJ, Saltiel AR (1995) A synthetic inhibitor of the mitogen-activated protein kinase cascade. Proc Natl Acad Sci USA 92:7686-7689.

Earnshaw WC (1995) Nuclear changes in apoptosis. Curr Opin Cell Biol 7:337-343.

Edwards SN, Buckmaster AE, Tolkovsky AM (1991) The death programme in cultured sympathetic neurones can be suppressed at the posttranslational level by nerve growth factor, cyclic AMP, and depolarization. J Neurochem 57:2140-2143.

Faure M, Voyno-Yasenetskaya TA, Bourne H (1994) cAMP and $\beta \gamma$ subunits of heterotrimeric $\mathrm{G}$ proteins stimulate the mitogen-activated protein kinase pathway in COS-7 cells. J Biol Chem 269:7851-7854.

Favit A, Scapagnini U, Canonico PL (1995) Pituitary adenylate cyclaseactivating polypeptide activates different signal transducing mechanisms in cultured cerebellar granule cells. Neuroendocrinology 61:377-382.

Frödin M, Peraldi P, Van Obberghen E (1994) Cyclic AMP activates the mitogen-activated protein kinase cascade in PC12 cells. J Biol Chem 269:6207-6214.

Galli C, Meucci O, Scorziello A, Werge TM, Calissano P, Schettini G (1995) Apoptosis in cerebellar granule cells is blocked by high $\mathrm{KCl}$, forskolin, and IGF-1 through distinct mechanisms of action: the involvement of intracellular calcium and RNA synthesis. J Neurosci 15:1172-1179.

Gallo V, Giovanini C, Levi G (1990) Modulation of non- $N$-methyl-Daspartate receptors in cultured cerebellar granule cells. J Neurochem 54:1619-1625.

Graves LM, Bornfeldt KE, Raines EW, Potts BC, McDonald SG, Ross R, Krebs EG (1993) Protein kinase A antagonizes platelet-derived growth factor-induced signaling by mitogen-activated protein kinase in human arterial smooth muscle cells. Proc Natl Acad Sci USA 90:10300-10304.

Hashimoto H, Ishihara T, Shigemoto R, Mori K, Nagata S (1993) Molecular cloning and tissue distribution of a receptor for pituitary adenylate cyclase activating polypeptide. Neuron 11:333-342.

Hernandez A, Kimball B, Romanchuk G, Mulholland MW (1995) Pituitary adenylate cyclase-activating peptide stimulates neurite growth in PC12 cells. Peptides 16:927-932.

Hockenberry D, Nuñez G, Milliman C, Schreiber RD, Korsmeyer SJ (1990) Bcl-2 is an inner mitochondrial membrane protein that blocks programmed cell death. Nature 348:334-336.

Ishihara T, Shigemoto R, Mori K, Takahashi K, Nagata S (1992) Functional expression and tissue distribution of a novel receptor for vasoactive intestinal polypeptide. Neuron 8:811-819.

Isokobe K, Nakai T, Takuwa Y (1993) $\mathrm{Ca}^{2+}$-dependent stimulatory effect of pituitary adenylate cyclase-activating polypeptide on catecholamine secretion from cultured porcine adrenal medullary chromaffin cells. Endocrinology 132:1757-1765.

Kew JN, Smith DW, Sofroniew MV (1996) Nerve growth factor withdrawal induces the apoptotic death of developing septal cholinergic neurons in vitro: protection by cyclic AMP analogue and high potassium. Neuroscience 70:329-339.

Lam D-C, Takahashi K, Ghatei MA, Kanse SM, Polak JM, Bloom SR (1990) Binding sites of a novel neuropeptide pituitary adenylate cyclase-activating polypeptide in the rat brain and lung. Eur J Biochem 193:725-729.

Landis DMD, Sidman RL (1978) Electron microscopic analysis of postnatal histogenesis in the cerebellar cortex of staggerer mutant mice. J Comp Neurol 179:831-864.
Levi G, Aloisi F, Ciotti MT, Gallo V (1984) Autoradiographic localisation and depolarisation-induced release of acidic amino acids in differentiating cerebellar granule cell cultures. Brain Res 290:77-86.

Lutz EM, Sheward WJ, West KM, Morrow JA, Fink G, Harmar AJ (1993) The VIP2 receptor: molecular characterisation of a cDNA encoding a novel receptor for vasoactive intestinal peptide. FEBS Lett 334:3-8.

Marini AM, Paul SM (1992) N-Methyl-D-aspartate receptor-mediated neuroprotection in cerebellar granule cells requires new RNA and protein synthesis. Proc Natl Acad Sci USA 89:6555-6559.

Mena MA, Casarejos MJ, Bonin A, Ramos JA, Garcia de Yébenes J (1995) Effects of dibutyryl cyclic AMP and retinoic acid on the differentiation of dopamine neurons: prevention of cell death by dibutyryl cyclic AMP. J Neurochem 65:2612-2620.

Miyata A, Arimura A, Dahl RR, Minamino N, Uehara A, Jiang L, Culler MD, Coy DH (1989) Isolation of a novel 38 residue-hypothalamic polypeptide which stimulates adenylate cyclase in pituitary cells. Biochem Biophys Res Commun 164:567-574.

Pang L, Sawada T, Decker SJ, Saltiel AR (1995) Inhibition of MAP kinase kinase blocks the differentiation of PC-12 cells induced by nerve growth factor. J Biol Chem 270:13585-13588.

Pincus DW, DiCicco-Bloom EM, Black IB (1990) Vasoactive intestinal peptide regulates mitosis, differentiation, and survival of cultured sympathetic neuroblasts. Nature 343:564-567.

Rawlings SR, Piuz I, Schlegel W, Bockaert J, Journot L (1995) Differential expression of pituitary adenylate cyclase-activating polypeptide vasoactive intestinal polypeptide receptor subtypes in clonal pituitary somatotrophs and gonadotrophs. Endocrinology 136:2088-2098.

Rosen LB, Ginty DD, Weber MJ, Greenberg ME (1995) Membrane depolarization and calcium influx stimulate MEK and MAP kinase via activation of Ras. Neuron 12:1207-1221.

Rydel RE, Greene LA (1988) cAMP analogs promote survival and neurite outgrowth in cultures of rat sympathetic and sensory neurons independently of nerve growth factor. Proc Natl Acad Sci USA 85:1257-1261.

Salomon Y, Londos C, Rodbell M (1974) A highly sensitive adenylate cyclase assay. Anal Biochem 58:541-548.

Sevetson BR, Kong X, Lawrence Jr JC (1993) Increasing cAMP attenuates activation of mitogen-activated protein kinase. Proc Natl Acad Sci USA 90:10305-10309.

Spengler D, Waeber C, Pantaloni C, Holsboer F, Bockaert J, Seeburg PH, Journot L (1993) Differential signal transduction by five splice variants of the PACAP receptor. Nature 365:170-175.

Virdee K, Tolkovsky AM (1995) Activation of p44 and p42 MAP kinases is not essential for the survival of rat sympathetic neurons. Eur J Neurosci 7:2159-2169.

Watanabe T, Masuo Y, Matsumoto H, Suzuki N, Ohtaki T, Masuda Y, Kitada C, Tsuda M, Fujino M (1992) Pituitary adenylate cyclase activating polypeptide provokes cultured rat chromaffin cells to secrete adrenaline. Biochem Biophys Res Commun 182:403-411.

Wood KA, Dipasquale B, Youle RJ (1993) In situ labelling of granule cells for apoptosis-associated DNA fragmentation reveals different mechanisms of cell loss in developing cerebellum. Neuron 11:621-632.

Wu J, Dent P, Jelinek T, Wolfman A, Weber MJ, Sturgill TW (1993) Inhibition of the EGF-activated MAP kinase signalling pathway by adenosine 3',5'-monophosphate. Science 262:1065-1069.

Wyllie AH (1980) Glucocorticoid-induced thymocytes apoptosis is associated with endogenous endonuclease activation. Nature 284:555-556.

Xia Z, Dickens M, Raingeaud J, Davis RJ, Greenberg ME (1995) Opposing effects of ERK and JNK-p38 MAP kinases on apoptosis. Science 270:1326-1331.

Yan G-M, Ni B, Weller M, Wood KA, Paul SM (1994) Depolarization or glutamate receptor activation blocks apoptotic cell death of cultured cerebellar granule neurons. Brain Res 656:43-51.

Yan G-M, Lin S-Z, Irwin RP, Paul SM (1995a) Activation of G proteins bidirectionally affects apoptosis of cultured cerebellar granule neurons. J Neurochem 65:2425-2431.

Yan G-M, Lin S-Z, Irwin RP, Paul SM (1995b) Activation of muscarinic cholinergic receptors blocks apoptosis of cultured cerebellar granule neurons. Mol Pharmacol 47:248-257.

Young SW, Dickens M, Tavaré JM (1994) Differentiation of PC12 cells in response to a cAMP analogue is accompanied by sustained activation of mitogen-activated protein kinase. FEBS Lett 338:212-216. 